\title{
THE EFFECT OF INTENSE RAINSTORM EVENTS ON THE SUSPENDED SEDIMENT RESPONSE UNDER VARIOUS LAND USES: THE AÍSA VALLEY EXPERIMENTAL STATION
}

\author{
E. NADAL-ROMERO ${ }^{(1)^{*}}$, T. LASANTA ${ }^{(2)}$, \\ J. C. GONZALEZ-HIDALGO ${ }^{(1)}$, \\ M. DE LUIS ${ }^{(1)}$, J. M. GARCÍA-RUIZ ${ }^{(2)}$ \\ ${ }^{1}$ Departamento de Geografía, Facultad de Filosofía y Letras, \\ Universidad de Zaragoza, 50009-Zaragoza, Spain. \\ ${ }^{2}$ Instituto Pirenaico de Ecología, CSIC, Campus de Aula Dei, \\ Apartado 13.034, 50080-Zaragoza, Spain.
}

\begin{abstract}
Time compression was studied at the Ais a Valley Experimental Station to assess the effect of large rainfall events on suspended sediment load. The study was focused on the response of land under traditional and current land uses/land covers in Mediterranean mountain areas, including dense shrub cover, grazing meadow, abandoned field, cereal cultivation, fallow land and both active and abandoned shifting agriculture. The results confirm the importance of the largest rainfall events in explaining the geomorphological effects that occur during a small number of such events. Three groups of land uses were distinguished: (i) dense shrub cover and grazing meadow, which showed relatively little time compression; (ii) cereal cultivation, fallow land, and both active and abandoned shifting agriculture, which were characterized by a high degree of time compression and a major impact of the largest events; and (iii) the abandoned field, which was intermediate in response between the other two groups. The greater geomorpho-logical effects of the largest events in the plots at the Aisa Valley Experimental Station relative to those reported in studies in the USA, is a consequence of the Mediterranean climate charac-teristics, and in part because of scale effects. The contribution of the three largest events to total accumulated suspended sediment load ranged from 25.4 to $71.2 \%$ whereas for the five largest events it ranged from 35.4 to $76.9 \%$. For each of the land uses the 25 largest events represented more than $80 \%$ (in some cases more than 90\%) of the total suspended sediment load recorded since 1991.
\end{abstract}

Key words: time compression, largest events, suspended sediment load, experimental plots, Mediterranean mountains. 
*Correspondencia: Departamento de Geografía, Facultad de Filosofía y Letras, Universidad de Zaragoza, 50009 Zaragoza, Spain. E-mail: estelanr@unizar.es

\section{Introduction}

Many studies of soil erosion have highlighted that a small number of short-term erosive events are responsible for a large proportion of the geomorphological effects and the sediment load (see González-Hidalgo et al., 2009, 2010, 2012, in press). This phenomenon is related to "time compression", which is defined as the shortest temporal interval producing most of the soil erosion or sediment load in a catchment during a defined period (one year). For example, in a study based on 310 plots from the Universal Soil Loss Equation (USLE) database, rainfall events representing $10 \%$ of the total daily erosion events yielded, on average, $50 \%$ of the total soil eroded (GonzálezHidalgo et al., in press). Furthermore, based on information from 1800 catchments in the USA and Canada, González-Hidalgo et al. (2011) found that the mean contribution of the 25 largest daily events produced $46-63 \%$ of the total sediment load, and the mean contribution of the five largest events was $23-39 \%$. They concluded that the relative contribution of different n-largest aggregated daily events to total suspended sediment loads generally decreases as catchment size increases, thus confirming that sediment delivery is a scale-dependent process (Thornes, 1999; de Vente and Poesen, 2005; de Vente et al., 2007; Nadal-Romero et al., 2011; Vanmaercke et al., 2011). This phenomenom was called "time compression".

In a review of the western Mediterranean basin, González-Hidalgo et al. (2007) found that on average the three largest daily events per year accounted for more than $50 \%$ of the total sediment carried out of the basin. Thus, time compression is particularly high under Mediterranean climate conditions, where intense rainstorms of more than $200 \mathrm{~mm}$ in 24 hours can cause the development of gullies, high rates of soil erosion in several hours and high sediment loads accompanying catastrophic floods (LópezBermúdez et al., 1979; López-Bermúdez and Romero-Díaz, 1992-1993; García-Ruiz et al., 1996; White et al., 1997; Poesen and Hooke, 1997; Schnabel et al., 1998; Llasat et al., 2003; Barrera et al., 2007; Barnolas et al., 2008).

Studies of soil erosion have increasingly focused on land use changes, because land cover is one of the most important factors explaining soil particle detachment and sediment delivery (Thornes, 1985; Descroix and Olivry, 2002; García-Ruiz et al., 2008; García-Ruiz, 2010; Nunes et al., 2010). Agricultural systems offer the potential to control the land cover and soil characteristics, providing opportunities for rainfall partitioning (i.e. infiltration, interception, overland flow) and soil improvement. Thus, in the design of soil and water conservation systems it is important to know the maximum average soil loss rate that still enables the maintenance of crop production (Burwell and Kramer, 1983), and also the effects of rare storms, which are key considerations in the design of conservation management systems (Larson et al., 1997). For these reasons, many studies worldwide have involved analysis of the hydrological and geomorphological responses of various land uses to normal and extreme events 
(e.g. Wischmeier, 1962; Hjelmfelt et al., 1986; Boardman et al., 1990; Zuzel et al., 1993; Zhang and Garbrecht, 2002; García-Ruiz et al., 2008, 2010). This is particularly the case for the Mediterranean region, where soil erosion is one of the major environmental problems, and where land use and land cover in both the highlands and lowlands have undergone major changes in recent decades (García-Ruiz et al., 1995, 1996; Debussche et al., 1999; MacDonald et al., 2000; Grove and Rackham, 2001; Taillefumier and Piégay, 2003; Rounsevell et al., 2006; López-Bermúdez and GarcíaRuiz, 2008; García-Ruiz and Lana-Renault, 2011). In particular, the recent expansion of vineyards and olive and almond tree orchards is well known to have caused an increase in soil erosion because of relatively steep slopes involved and the relative absence of plant cover protecting the soil surface during some months of the year (Giráldez et al., 1989; Kosmas et al., 1997; Poesen et al., 1997; Gómez et al., 2004; Ramos and Martínez-Casasnovas, 2009). In addition, the abandonment of cereal cropping in mountain areas and the subsequent plant recolonization have caused major changes in the hydrological functioning of the hillslopes (Llorens et al., 1992; RuizFlaño et al., 1992; Gallart et al., 1994; Lasanta et al., 2010; García-Ruiz and LanaRenault, 2011).

In terms of the relationship between time compression and land use, it is evident that the hydrological and geomorphological response to rainstorms of varying intensity is highly variable with respect to factors related to land cover (e.g. the density and composition of vegetation, soil depth, infiltration capacity). However, no comparisons have been made of the hydromorphological behaviour of land under different land uses and the importance of erosion during the most intense rainstorm events. The main purpose of this study was to analyze the sediment yield from various land uses during extreme rainstorm events, using information from the Aísa Valley Experimental Station, Central Pyrenees. The land uses analyzed included various land management systems traditionally used in mountain areas and others that characterize current land uses in circumstances where most of the land has been abandoned or misused. The importance of this issue would increase in coming decades, as climate change studies suggest that the contribution of extreme rainfall events to total annual precipitation may increase (Giorgi, 2002; Räisänen et al., 2004; Zolina et al., 2004; Kundzewicz et al., 2006; López-Moreno and Beniston, 2009; Burgueño et al., 2010).

\section{The study area}

The study was carried out at the Aísa Valley Experimental Station, which is in the Aísa Valley, near the village of Aísa (1 km distant), in the Central-Western Pyrenees. Since 1991 the station has been acquiring data on hydrological and erosive responses under various land uses (fig. 1). It is located at $1240 \mathrm{~m}$ a.s.1., on a south facing slope (32\% of gradient) that was cultivated until 45 years ago and then abandoned. The bedrock is composed of alternating thin beds of sandstones and marls approximately 10 $\mathrm{cm}$ thick, belonging to the Eocene flysch series, and is intensively folded and faulted. The relief is characterized by smooth divides, which correspond to old erosion levels, 


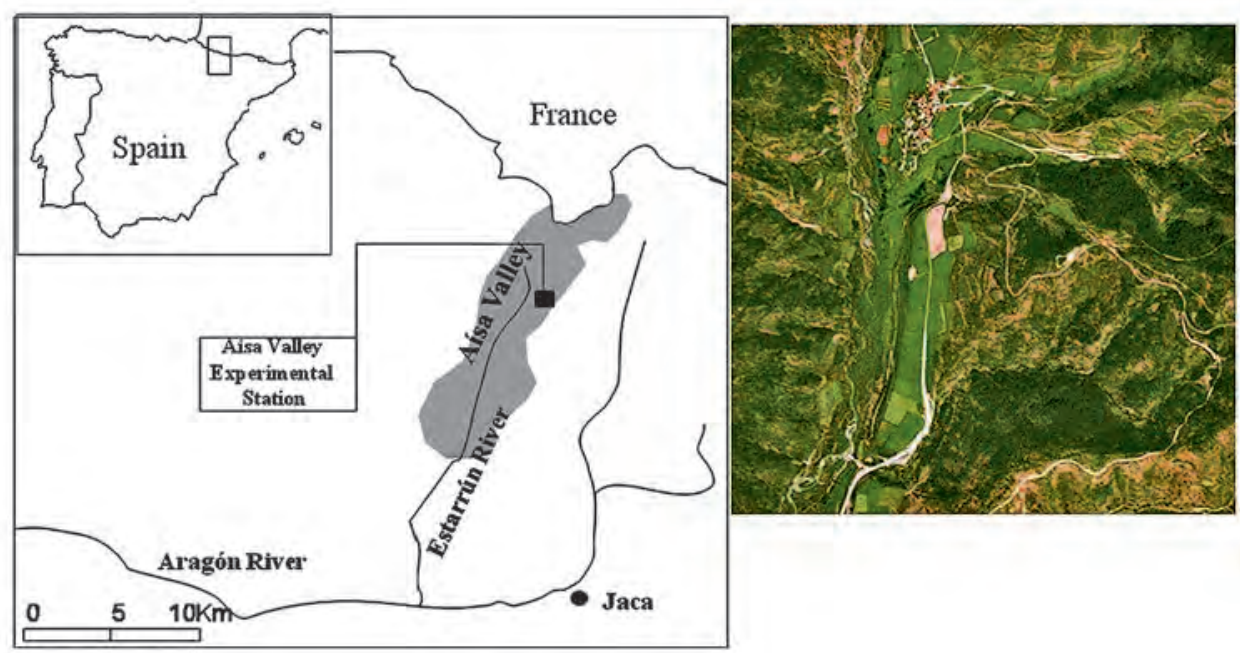

Figure 1. Location of the Aísa Valley Experimental Station.

and regularized slopes covered by a colluvium that is occasionally mobilized by shallow landslides that evolve into debris flows (García-Ruiz and Puigdefábregas, 1982; Lorente et al., 2002). The soils are brown and very stony, low in nutrients and organic matter (1.5\%), and rich in carbonates that ensure the $\mathrm{pH}$ is always basic (RuizFlaño, 1993). The average annual precipitation in the village of Aísa (at $1100 \mathrm{~m}$ a.s.1.) is approximately $1100 \mathrm{~mm}$, and the average temperature is $10^{\circ} \mathrm{C}$. The main rainfall period is from November to June, with a slight decrease in winter (fig. 2). The summers are relatively dry.

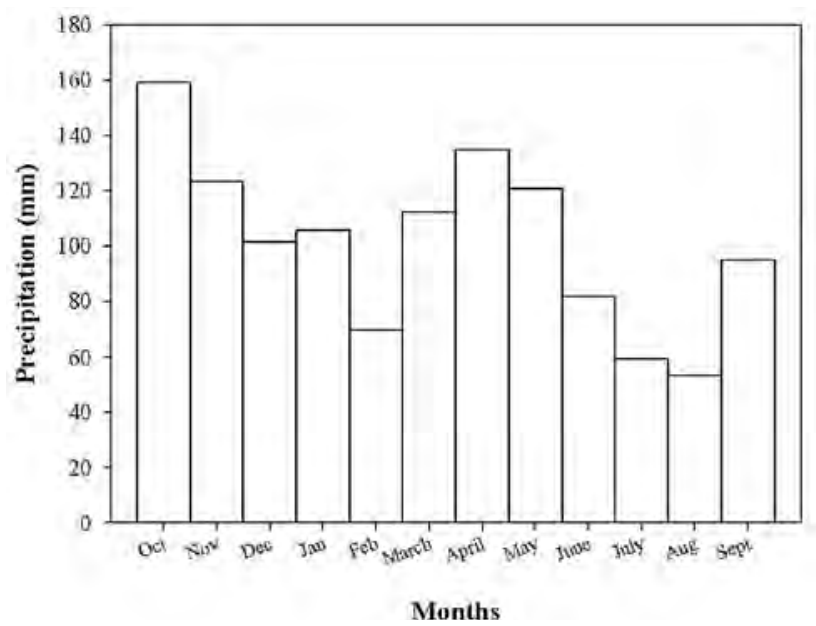

Figure 2. Distribution of monthly precipitation at Aísa. 
Most of south-facing slopes located below $1600 \mathrm{~m}$ a.s.l. were cultivated until the beginning of the 20th century, coinciding historically with the greatest population pressure. At that time, the straight and concave slopes were cultivated as slightly benchterraced fields (alternating one year of cultivation followed by a year of fallow), whereas convex slopes were occasionally cultivated under a shifting agriculture system (3-5 years of cultivation in every 25-30 years). Cereals were the main crop. From the beginning of the 20th century most of the cultivated fields were abandoned, firstly those under shifting agriculture, and then those located on the hillslopes (Lasanta, 1988, 1989). Only the fields located in the valley floor are presently cultivated, mainly with meadows for hay production (cutting meadows). Some of the abandoned fields close to the villages supported relatively high livestock pressure, and have been converted to grazing meadows. Most of the abandoned fields were subject to a complex process of plant recolonization (Lasanta and Vicente-Serrano, 2007), which commenced with the development of a herbaceous cover that was followed by the appearance of shrubs dominated by Genista scorpius accompanied by Rosa gr. canina, Juniperus communis, Echynospartum horridum and Crataegus monogyna. Until some decades ago fields with having a dense cover of thorny shrubs were frequently burnt to enable extensive grazing by sheep herds, but this caused major erosion problems and soil degradation (Ruiz-Flaño et al., 1992). This practice is now forbidden, which has resulted in a generalized expansion of shrubs.

\section{Material and methods}

Nine closed plots were established at the Aísa Valley Experimental Station in 1991 to facilitate controlled studies of the hydromorphological behaviour of traditional and current land management practices in the Pyrenees (fig. 3). Each plot (10 x $3 \mathrm{~m}$ ) has a Gerlach canal in the lowest part to collect runoff and sediment yield during rainstorm events. The canal directs water and sediment to tipping buckets connected to data loggers, and then to plastic collectors (220 litres capacity). After each rainfall event 1 litre of the water stored was taken from each collector to measure the suspended sediment concentration and solute composition. Each year a vegetation sampling was performed in every plot to estimate the percentage of herbs and shrubs covering, and the most abundant species were identified. The land uses in the nine plots were as follows:

(i) Dense shrub cover. This plot represents the natural, undisturbed plant cover several decades following farmland abandonment (fig. 4).

(ii) Grazing meadow. This plots represents the natural evolution of a regularly grazed abandoned field (fig. 5).

(iii) Cereal (barley), with added chemical fertilizer. This plot represents traditional cultivation on sloping fields (although chemical fertilizer was used instead of livestock manure).

(iv) Abandoned field. This plot (abandoned in 1993 following two years of cereal cultivation) represents the natural evolution of an abandoned field during the 


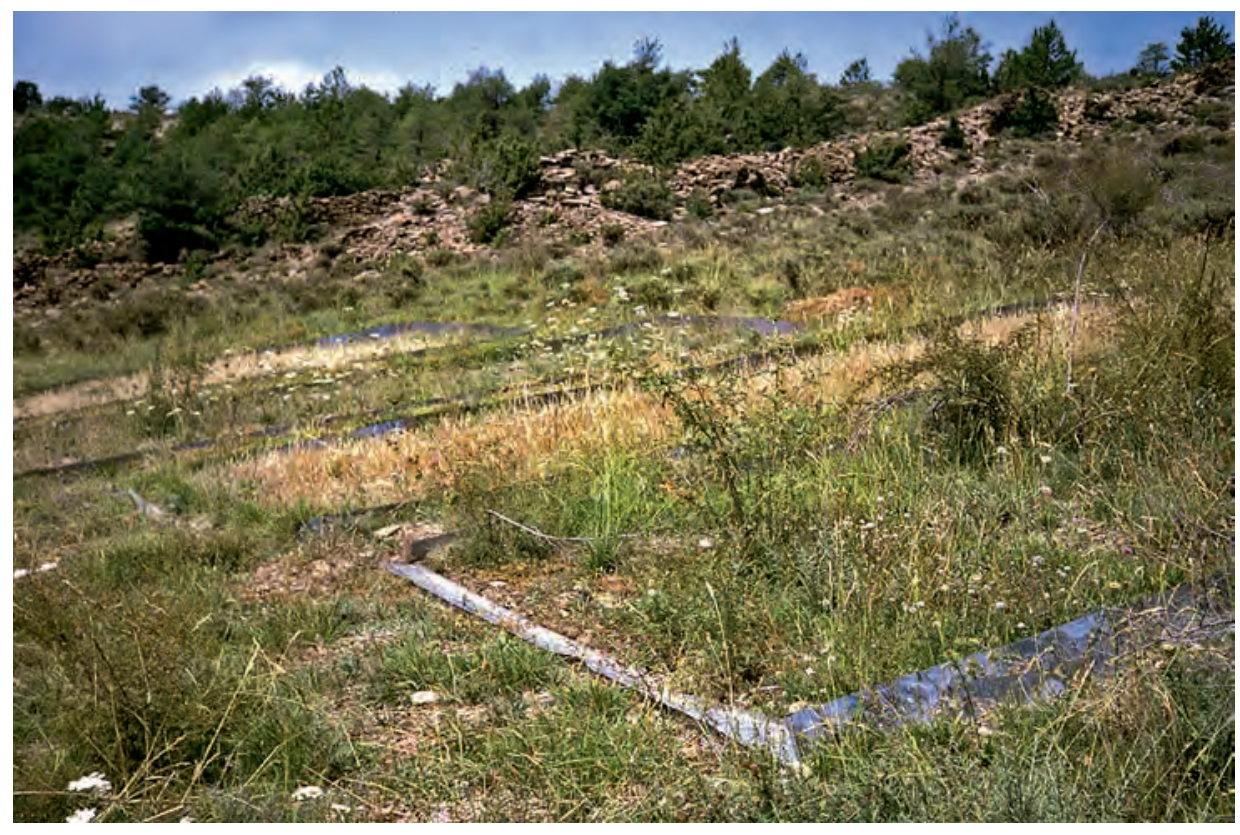

Figure 3. A perspective of the Aisa Valley Experimental Station.

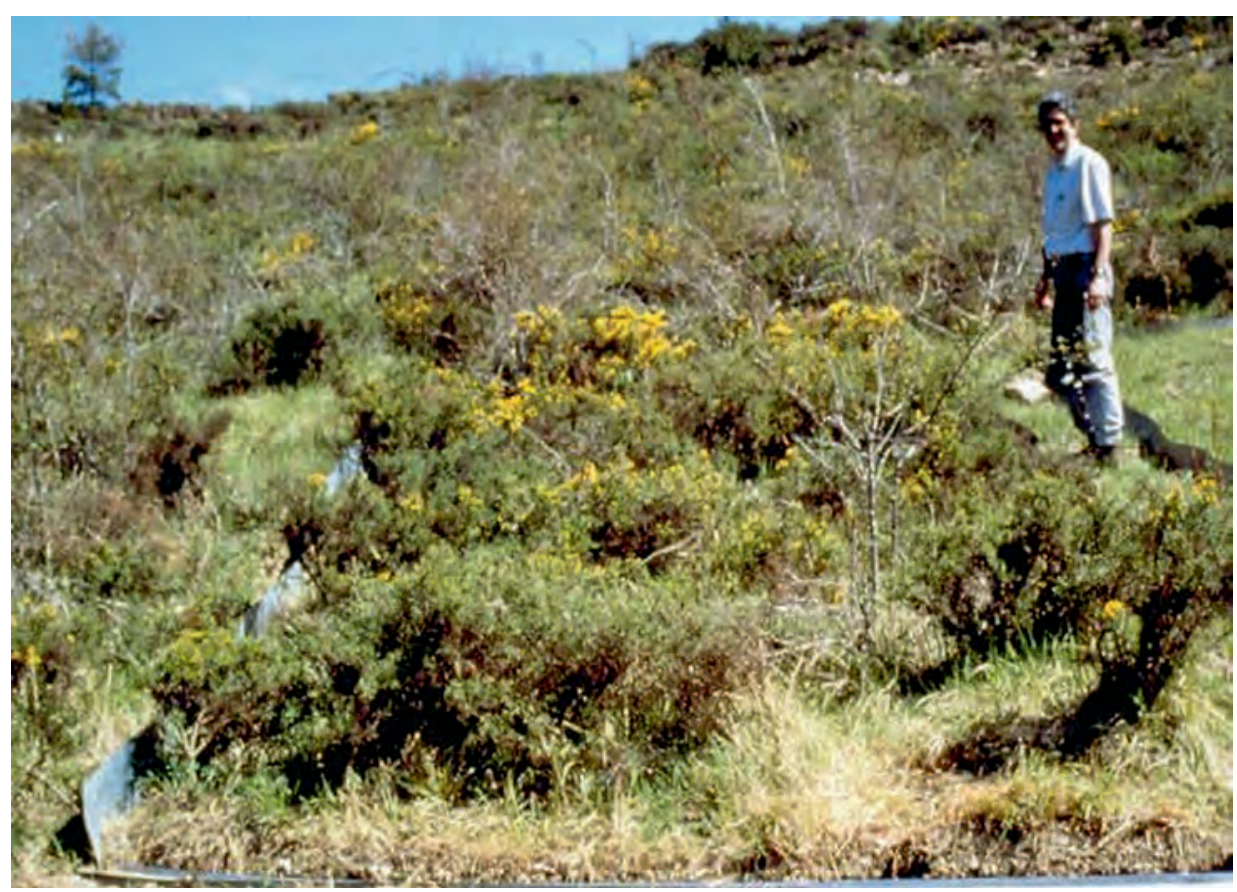

Figure 4. The dense shrub cover plot in 2011. 


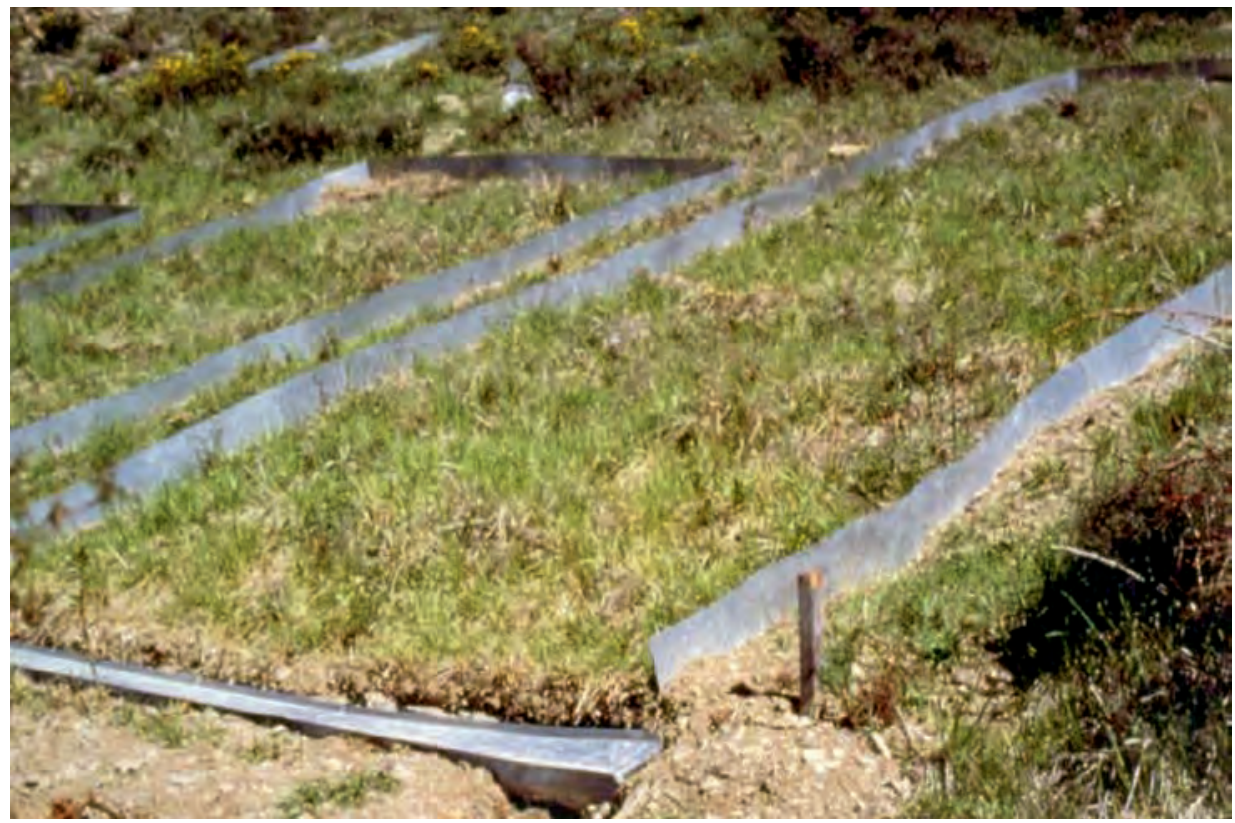

Figure 5. The grazing meadow plot.

years immediately following abandonment, which was dominated successively by open herbs, a dense herbaceous cover, and a progressive colonization by shrubs.

(v) Fallow. This represents the year following cereal cultivation, during which the field was left fallow and the soil was ploughed one or more times such that it remained without plant cover. In this plot fallow alternated annually with cereal cultivation, as in the traditional agricultural system.

(vi) Active shifting agriculture plot, cultivated with cereal under extreme conditions. In this case the shrubs (mainly Genista scorpius) on the original plot were cut, piled up, covered with earth, and then burnt slowly. The ashes were distributed in the plot as fertilizer, according to the traditional management of these shifting agriculture fields (fig. 6) (Lasanta et al., 2006). This fertilization system supplies few nutrients to the soil, as the ashes represent only $2.5 \%$ of the plant, and have only a low content of $\mathrm{N}(1.24 \%), \mathrm{P}(0.05 \%), \mathrm{K}(0.29 \%), \mathrm{Ca}(0.53 \%)$ and $\mathrm{Mg}$ (0.08\%) (Lasanta et al., 2006).

(vii) Abandoned shifting agriculture. This plot was abandoned in 1996 following four years of cereal cultivation under a shifting agriculture system. Its evolution following farmland abandonment was slower than that of a "normal" abandoned field (plot iv), as it received ashes as the only fertilizer when it was cultivated. 


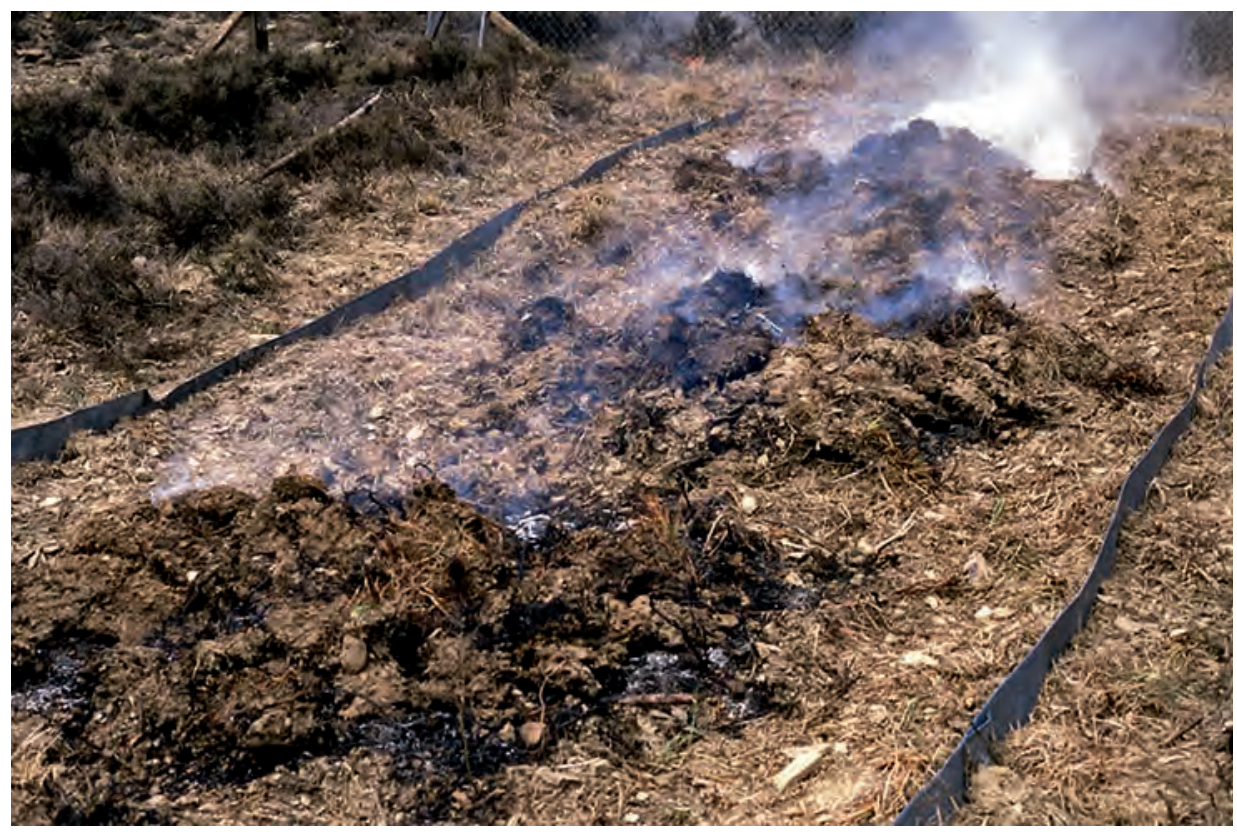

Figure 6. Preparation of the shifting agriculture plot. The shrubs were cut, piled up and covered by earth, then they burnt. The ashes were distributed in the plot as fertilizer.

Two additional plots (one burnt in 1991, and the other burnt in 1993 and 2001) were monitored, although they were not included in the analysis in this study because they were not representative of land uses in the study area.

It is important to take into account the limitations of data obtained from experimental plots. These have been highlighted by Boix-Fayos et al., (2006, 2007), and in particular include a trend to sediment exhaustion, the effects of the plot borders on sediment yield, and the disconnection of the plot from the natural overland flow of the hillslope. For these reasons, the results obtained from experimental plots must be treated with caution, and only used for comparative purposes, as was the case in this study.

This study used rainfall, discharge and suspended sediment yield data obtained over 19 hydrological years (October to September) from 1991 to 2010. Due to methodological errors, only events where the sediment yield was higher than $0.1 \mathrm{~g} \mathrm{~m}^{-2}$ were selected for inclusion in the analysis, and consequently the number of events included differed for each land use plot (181 events for the dense shrub cover plot, 292 for the fallow land plot, 287 for the cereal plot, 230 for the abandoned field plot, 214 for the grazing meadow plot, 235 for the abandoned shifting agriculture plot, and 295 for the active shifting agriculture plot). The selected events were ranked from the largest to the smallest in terms of the magnitude of the sediment yield, and the respective amounts of sediment, rainfall and runoff were calculated to obtain the percentage contribution from each event. 


\section{Results}

Table 1 shows the differences between land uses in relation to the maximum erosive event recorded in each plot. The dense shrub cover and the grazing meadow had a maximum event sediment yield in the order of 200-300 $\mathrm{g} \mathrm{m}^{-2}$, followed by the abandoned field $\left(1144 \mathrm{~g} \mathrm{~m}^{-2}\right)$, and the cereal $\left(2532 \mathrm{~g} \mathrm{~m}^{-2}\right)$ plots. High values were recorded from the abandoned shifting agriculture plot $\left(3779 \mathrm{~g} \mathrm{~m}^{-2}\right)$ and the active shifting agriculture (4622 $\mathrm{g} \mathrm{m}^{-2}$ ) plots, and the highest yield was recorded from the fallow land plot (almost 10000 $\mathrm{g} \mathrm{m}^{-2}$ ). This demonstrates that these latter land uses are prone to high erosion rates during the most intense rainfall events. During the most intense rainfall event recorded during the study period (1991-2010) the fallow land plot yielded approximately 45-fold more sediment than the grazing meadow plot, and about 30-fold more than the dense shrub cover plot. The differences were much lower in the case of runoff, although the highest levels were still recorded from the fallow land and the active shifting agriculture plots also. Nevertheless, runoff from the fallow land plot was approximately 5-fold that recorded for the grazing meadow plot.

It is notable that the largest rainfall event recorded at the Aísa Valley Experimental Station during the study period ( $285 \mathrm{~mm}$ over 20 days) corresponds to a return period of 11.7 years, based on the method of Landwehr et al. (1979). Thus, while it was a very intense rainstorm event, it was neither rare nor extreme.

Table 1. The maximum erosive event in each plot and the corresponding precipitation, runoff and runoff coefficients.

\begin{tabular}{|l|c|c|c|c|c|}
\hline \multicolumn{1}{|c|}{ Land uses } & $\begin{array}{c}\text { Max. Sedim } \\
\text { yield }\left(\mathrm{g} \mathrm{m}^{-2}\right)\end{array}$ & $\begin{array}{c}\text { Precipitation } \\
(\mathrm{mm})\end{array}$ & $\begin{array}{c}\text { Runoff } \\
\left(\mathbf{~ m}^{-2}\right)\end{array}$ & $\begin{array}{c}\text { Runoff } \\
\text { coefficient }\end{array}$ & Date \\
\hline Dense shrub cover & 313 & 228.2 & 43.5 & 19.1 & $21 / 12 / 2000-12 / 01 / 2001$ \\
\hline Grazing meadow & 220 & 79.8 & 37.8 & 47.3 & $23 / 03 / 1993-26 / 03 / 1993$ \\
\hline In-fallow plot & 9944 & 228.2 & 201.7 & 88.0 & $21 / 12 / 2000-12 / 01 / 2001$ \\
\hline Abanoned field & 1144 & 228,2 & 60.8 & 26.3 & $21 / 12 / 2000-12 / 01 / 2001$ \\
\hline Cereal (barley) & 2532 & 74.8 & 13.7 & 18.0 & $05 / 03 / 2001-12 / 03 / 2001$ \\
\hline $\begin{array}{l}\text { Abandon. shifting } \\
\text { agricult. plot }\end{array}$ & 3789 & 228.2 & 113.5 & 49.7 & $21 / 12 / 2000-12 / 01 / 2001$ \\
\hline $\begin{array}{l}\text { Active shifting } \\
\text { agricult. plot }\end{array}$ & 4622 & 116.6 & 178.5 & 26.0 & $26 / 03 / 1992-03 / 04 / 1992$ \\
\hline
\end{tabular}

Table 2 shows the accumulated percentage of sediment yield represented by the 1st, 2nd, 3rd, 5th, 10th and 25th largest events. Not surprisingly, the relative yield from each land use plot changed as more events are accumulated. For instance, the first event, represented a small proportion of the total sediment output for the grazing meadow plot 
(11.7\%), abandoned (19.3\%), the active shifting agriculture (16.1\%), cereal (16.8\%), and dense shrub cover $(24.7 \%)$ plots, while greater proportions were associated with the fallow land $(48.2 \%)$ and the abandoned shifting agriculture (50.4\%) plots. Accumulation of the 2nd and 3rd events produced similar relationships amongst the various land uses. For the five first events, three groupings of land use plots were identified: (i) the grazing meadow (35.4\%), abandoned field (45.2\%), dense shrub cover (46.2\%) plots; (ii) the cereal (48.5\%) and active shifting agriculture $(57.7 \%)$ plots; and (iii) the abandoned shifting agriculture $(71.3 \%)$, and the fallow land $(76.9 \%)$ plots. When the first 25 accumulated events were considered, only two groupings of land use plots were identified: (i) the dense shrub cover (80.2\%), abandoned field (83.8\%), and grazing meadow (84.2\%) plots; and (ii) the cereal $(87 \%)$, abandoned shifting agriculture $(90.8 \%)$, fallow land $(91.7 \%)$ and active shifting agriculture $(92.3 \%)$ plots.

Table 2. Percentage sediment yield represented by the 1 st, $2 \mathrm{nd}, 3 \mathrm{rd}, 5 \mathrm{th}, 10 \mathrm{th}$ and 25 th events among the various land uses.

\begin{tabular}{|c|c|c|c|c|c|c|c|}
\hline & Shrub & In-fallow & Cereal & Abandoned & Meadow & Shifft. a & Shift. B \\
\hline 1 event & 24.7 & 48.2 & 16.8 & 19.3 & 11.7 & 50.4 & 16.1 \\
\hline 2 events & 32.6 & 61.8 & 29.7 & 32 & 19.6 & 60.2 & 28.9 \\
\hline 3 events & 37.3 & 71.2 & 36.2 & 37.9 & 25.4 & 66.5 & 40.3 \\
\hline 5 events & 46.2 & 76.9 & 48.5 & 45.2 & 35.4 & 71.3 & 57.7 \\
\hline 10 events & 60.3 & 83 & 68 & 60.4 & 56.2 & 78.3 & 82.2 \\
\hline 25 events & 80.2 & 91.7 & 87 & 83.8 & 84.2 & 90.8 & 92.3 \\
\hline
\end{tabular}

Tables 3 and 4 confirm that in terms of 10th and 20th percentiles of precipitation, runoff and sediment yield, a small proportion of the precipitation events produced disproportionate hydrological and sediment yield events; that is, the most intense rainfall events generated high proportions of runoff that was very heavily loaded with suspended sediment. Thus, in the case of the dense shrub cover, $23.7 \%$ of precipitation produced $36.7 \%$ of the runoff and $74.2 \%$ of the sediment yield. In the case of the active shifting agriculture plot, $28.6 \%$ of the precipitation produced $53.1 \%$ of the runoff and $93.6 \%$ of the sediment yield. However, the most noteworthy result was that the differences between land uses were cushioned with respect to the 20th percentile, with very similar values of sediment yield being found amongst the various uses (the extreme values were $87.4 \%$ for the dense shrub cover plot and $97 \%$ for the fallow land plot). Few changes in the proportion of sediment yield were observed for some land uses when the 10th and 20th percentiles were compared, particularly in the case of the fallow plot, and both the abandoned and active shifting agriculture plots. 
Table 3. The 10th percentile of rainfall, runoff and sediment yield for the various land uses.

\begin{tabular}{|l|c|c|c|}
\hline Land uses/land covers & Precipitation & Runoff & Sediment yield \\
\hline Dense shrub cover & 23.74 & 36.76 & 74.2 \\
\hline Fallow land & 27.47 & 50.02 & 93.14 \\
\hline Cereal (barley) & 27.45 & 49.07 & 88.77 \\
\hline Abandoned land & 25.78 & 43.13 & 81.71 \\
\hline Meadow & 25.05 & 39.90 & 80.97 \\
\hline Abandoned shifting agriculture & 26.78 & 44.01 & 90.40 \\
\hline Active shifting agriculture & 28.56 & 53.10 & 93.62 \\
\hline
\end{tabular}

Table 4. The 20th percentile of rainfall, runoff and sediment yield for the various land uses.

\begin{tabular}{|l|c|c|c|}
\hline Land uses/land covers & Precipitation & Runoff & Sediment yield \\
\hline Dense shrub cover & 40.95 & 54.60 & 87.42 \\
\hline Fallow land & 45.25 & 69.08 & 97.04 \\
\hline Cereal (barley) & 44.81 & 66.22 & 94.45 \\
\hline Abandoned land & 43.12 & 65.75 & 92.99 \\
\hline Meadow & 43.30 & 60.69 & 90.04 \\
\hline Abandoned shifting agriculture & 44.09 & 62.39 & 95.08 \\
\hline Active shifting agriculture & 46.13 & 70.74 & 96.77 \\
\hline
\end{tabular}

Figure 7 shows the accumulated precipitation, runoff and sediment yield events for each land use. All the plots showed a similar pattern, with a high proportion of runoff and an even higher proportion of suspended sediment yield associated with the first 20-30\% of the events. The most notable differences were that: (i) the distance between the curves of the accumulated precipitation and runoff were least for the dense shrub cover, grazing meadow and cereal plots, and (ii) the most rapid change in the accumulated suspended sediment yield corresponded to the fallow and active shifting agriculture plots.

Figure 8 shows the accumulated sediment yield events arranged from the highest to the lowest value, providing a comparison of the dense shrub cover plot with the other land uses. All of the land uses showed a rapid increase in terms of the percentage sediment yield in the initial accumulation events (indicating the concentration of sediment yield into a small number events), such that almost no increase in sediment yield occurred after the first $15-20 \%$ of events. Nevertheless, there were some substantial differences amongst the land uses. The dense shrub cover plot showed the slowest change, indicating that the effect of the extreme events was relatively moderate. Similar results were found for the grazing meadow and the abandoned field plots. The greatest differences occurred in the fallow land and the active shifting agriculture plots, confirming that few events produced a very high proportion of the sediment yield. 

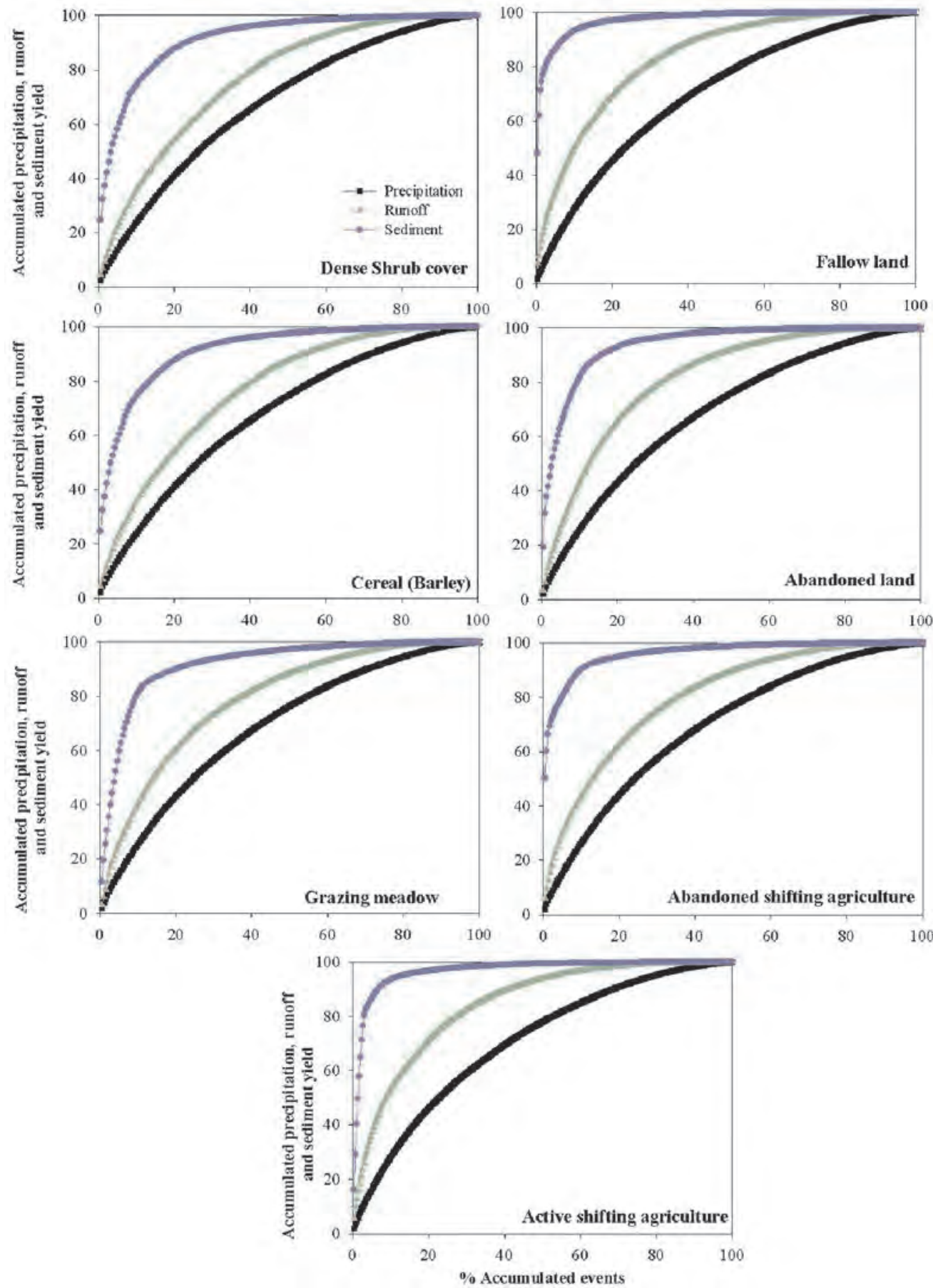

Figure 7. Accumulated precipitation, runoff and suspended sediment yield events for each land use. 

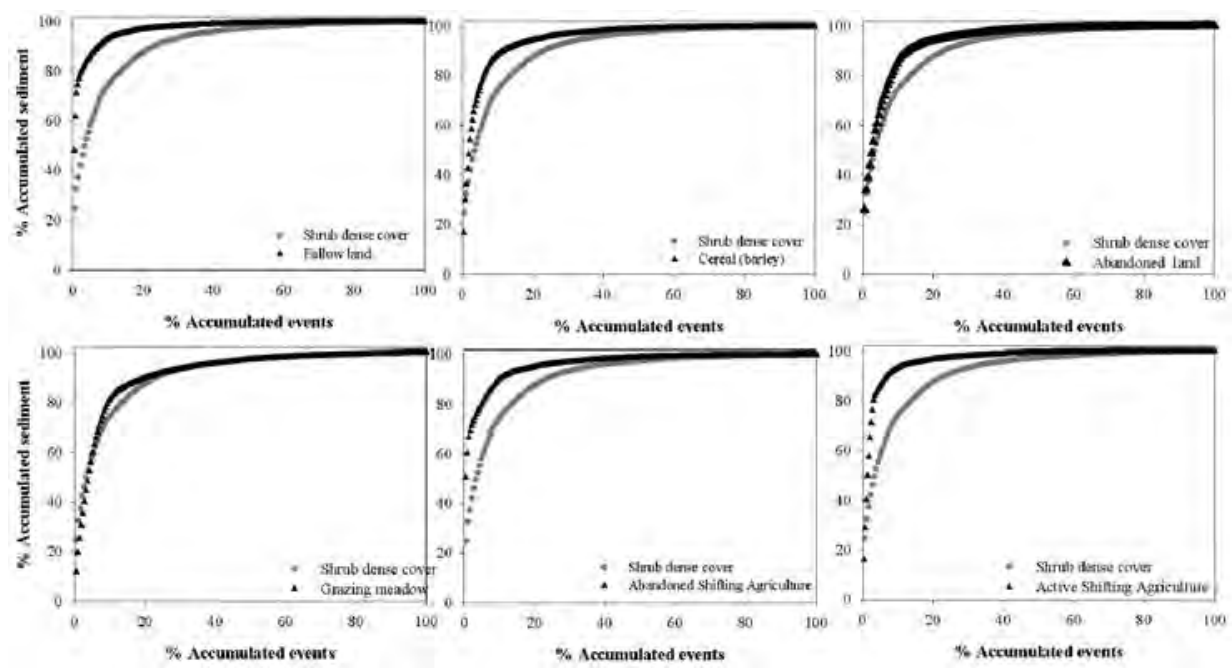

Figure 8. Comparison of accumulated sediment events between the dense shrub cover plot and the other land uses.

\section{Discussion and conclusions}

Despite their limitations, experimental plots can produce results enabling comparison of differing aspects of the hydromorphological behaviour of various land covers and land uses. From the results obtained we conclude that: (i) sediment yield is extremely temporally concentrated (high time compression) under Mediterranean climatic conditions; and (ii) there are large differences among land uses in the proportion of sediment yield produced by the maximum events.

The first conclusion confirms the results of earlier studies involving a diversity of spatial scales and environments (Meade et al., 1990; Lenzi et al., 2003; Lewis et al., 2005). The major geomorphological work occurs during few events (mainly during 1$5 \%$ of the time). For instance, Wei et al. (2010) concluded that three rainfall events were responsible for more than $50 \%$ of sediment outputs in the Kamech Dam (Tunisia) between 1994 and 2002. A similar result was found by González-Hidalgo et al. (2007) in western Mediterranean areas, where three daily erosive events per annum represented more than $50 \%$ of soil erosion, regardless of the total amount of soil eroded. Thus, González-Hidalgo et al. (2009) reported that a relatively long period of collection of sedimentary records is necessary to provide realistic estimates of average erosion rates. Such events can exhaust sediment at the basin scale, reducing sediment supply for many years (Alvera and García-Ruiz, 2000) and can result in marked changes to hillslope and channel dynamics, producing deep-seated and shallow landslides, gullies, channel erosion, braiding-dominated channels, and large volumes of suspended sediment load and bedload (García-Ruiz et al., 2002). Relative to previous studies, time compression 
was clearly greater at the Aísa Valley Experimental Station. Thus, in a case study involving 1800 catchments in the USA and Canada, the mean contribution of the 25 largest daily events varied from 46 to $63 \%$ of the total sediment yield, and the contribution of the five largest events varied from 23 to 39\% (González-Hidalgo et al., in press). In this study, the sediment concentration for the largest 25 events exceeded $80 \%$ for each land use, and for some land uses it exceeded $90 \%$ (fallow land, abandoned and active shifting agriculture plots). For the five largest events, the average contribution of the various land uses varied from 35.4 to $76.9 \%$. This was attributed to a scale effect, whereby the relative contribution of maximum events to total sediment transport increases as the size of the drainage area decreases (González-Hidalgo et al., in press). Studies of catchments and plots in the USA confirm that most of the geomorphic work occur over a short time period with, $30 \%$ of the suspended sediment yield generally occurring in only $1 \%$ of the time (catchment scale), and $50 \%$ of the soil being eroded in $10 \%$ of the time (plot scale) (González-Hidalgo et al., 2010, in press). At the Aísa Valley Experimental Station, irrespective of land use the events corresponding to the first $1 \%$ contributed with more than $30 \%$, and in some cases $>60 \%$ (fallow land and abandoned shifting agriculture plots). The return period estimated for the largest rainfall event recorded during the study period at the Aísa Valley Experimental Station demonstrates that extreme events (i.e. very rare events behaving as outliers in a time series) are not required for very high erosion rates to occur.

The second conclusion refers to the erosive response of various land uses to the most intense events. With respect to traditional and current land uses in Mediterranean mountain areas, three groups of land uses were distinguished:

(i) The dense shrub cover and the grazing meadow plots showed the least time compression, suggesting a moderate response to the most intense rainstorm events. Both land covers had the lowest values of sediment yield during the extreme events recorded (30- to 40-fold less than the most erosive land uses).

(ii) The fallow land, abandoned shifting agriculture and active shifting agriculture plots showed high time compression, with most of the sediment yield occurring during few events that were associated with very high levels of soil erosion. The cereal plot was also included in this group. These land uses have (a) an almost permanent absence of plant cover (fallow land plot), (b) very low crop production and consequently a low level of plant cover (active shifting agriculture plot), (c) slow plant recolonization following abandonment (abandoned shifting agriculture plot), or (d) a period without plant cover prior to cereal growth in spring (cereal plot). The cereal plot was unusual in that it showed a slow increase in the proportion of sediment yielded during the largest accumulation events, then a sudden increase in the proportion. Thus, during the most extreme events the cereal plot behaved in a similar way to the dense shrub cover, abandoned and grazing meadow plots. However, after 25 accumulated events it behaved like the fallow land and shifting agriculture plots. This suggests a relatively homogeneous response of the cereal plot to the most extreme events (i.e. the largest 25 accumulated events). 
(iii) The abandoned plot was intermediate between the two previous groups, although it was more similar to the former. The information base for this plot included rainfall, runoff and sediment yield events since 1993, when the plot was abandoned following two years of cereal cropping. Thus, at the beginning of the record the soil was poorly protected by plant cover, and only over several subsequent years did a dense herb and shrub cover develop. Consequently, at present this plot behaves like the grazing meadow or the dense shrub cover plots, although in its record there is evidence of the first years of abandonment.

From a soil erosion and sediment yield point of view several conclusions are evident. Firstly, under traditional practices soil erosion mainly affected cultivated hillslopes, particularly when these were in fallow or under shifting agriculture. Based on the high levels of sediment yield from such land uses during the most intense rainstorm events, it is likely that these practices were largely responsible for soil degradation following decades and in some cases centuries of cultivation in topographically marginal areas (García-Ruiz and Valero-Garcés, 1998). Secondly, farmland abandonment resulted in a progressive change in the hydromorphological behaviour of formerly cultivated hillslopes, as a consequence of gradual plant recolonization. At present, this plot is behaving in a similar way to the grazing meadow and dense shrub cover plots. The change in use of fields on steep slopes from cultivation to shrub colonization or grazing meadows has clearly reduced the erosion risk during extreme events, contributing to a widespread hydromorphological change in the Central Pyrenees and other Mediterranean mountains (Pardini et al., 2004; Beguería et al., 2006; Bathurst et al., 2007; Lasanta et al., 2010; Morán-Tejeda et al., 2010; Nunes et al., 2010; García-Ruiz et al., 2011; GarcíaRuiz and Lana-Renault, 2011).

\section{Acknowledgements}

Support for this research was provided by the projects PROBASE (CGL200611619/HID), HIDROCAES (CGL2011-27574-C02-01 and 02) and INDICA (CGL201127753-C02-01 and -02), funded by the Spanish Ministry of Education and Science, and ACQWA (FP7-ENV-2007-1-212250), financed by the European Commission. Monitoring of the Aísa Valley Experimental Station was supported by an agreement between the CSIC and the Spanish Ministry of Environment (RESEL). The first author benefited from a research contract (Spanish Ministry of Science and Innovation, Programme Juan de la Cierva).

\section{References}

Alvera, B., García-Ruiz, J. M. (2000). Variability of sediment yield from a high mountain catchment, Central Spanish Pyrenees. Arctic, Antarctic and Alpine Research, 32 (4): 478-484. 
Barnolas, M., Atencia, A., Llasat, M. C., Rigo, R. (2008). Characterization of a mediterranean flash flood event using rain gauges, radar, GIS and lightning data. Advances in Geosciences, 17: 35-41.

Barrera, A., Altava Ortiz, V., Llasat, M. C., Barnolas, M. (2007). Heavy rain prediction using deterministic and probabilistic models - the flash flood cases of 1113 October 2005 in Catalonia (NE Spain). Advances in Geosciences 12: 121-126.

Bathurst, J. C., Moretti, G., El-Hames, A., Beguería, S., García-Ruiz, J. M. (2007). Modelling the impact of forest loss on shallow landslide sediment yield, Ijuez catchment, Spanish Pyrenees. Hydrology and Earth System Sciences, 11 (1): 569-583.

Beguería, S., López-Moreno, J. I., Gómez-Villar, A., Rubio, V., Lana-Renault, N., García-Ruiz, J. M. (2006). Fluvial adjustment to soil erosion and plant cover changes in the Central Spanish Pyrenees. Geografiska Annaler, 88A (3): 177-186.

Boardman, J., Foster, I. D. L., Dearing, J. A., eds. (1990). Soil Erosion on Agricultural Lands. J. Wiley \& Sons, Chichester, $687 \mathrm{pp}$.

Boix-Fayos, C., Martínez-Mena, M., Arnau-Rosalén, E., Calvo-Cases, A., Castillo, V., Albaladejo, J. (2006). Measuring soil erosion by field plots: understanding the sources of variation. Earth-Science Reviews, 78: 267-285.

Boix-Fayos, C., Martínez-Mena, M., Calvo-Cases, A., Arnau-Rosalén, E., AlbaLADEJo, J., CASTILlO, V. (2007). Causes and underlying processes of measurement variability in field erosion plots in Mediterranean conditions. Earth Surface Processes and Landforms, 32: 85-101.

Burgueño, A., Martínez, M. D., Serra, C., Lana, X. (2010). Statistical distributions of daily rainfall regime in Europe for the period 1951-2000. Theoretical and Applied Climatolology, 102: 213-226.

Burwell, R. E., Kramer, L. A. (1983). Long-term annual runoff and soil loss from conventional conservation tillage corn. Journal of Soil and Water Conservation, 38: 315-319.

De Vente, J., Poesen J. (2005). Predicting soil erosion and sediment yield at the basin scale: Scale issues and semi-quantitative models. Earth-Science Reviews, 71: 95-125.

De Vente, J., Poesen, J., Arabkhedri, M., Verstraeten, G. (2007). The sediment delivery problem revisited. Progress in Physical Geography, 31(2): 155-178.

Debussche, M., Lepart, J., Dervieux, A. (1999). Mediterranean landscape changes: evidence from old postcards. Global Ecology and Biogeography, 8: 3-15.

Descroix, L., Olivry, J. C. (2002). Spatial and temporal factors of erosion by water of black marls in the badlands of the French Southern Alps. Hydrological Sciences Journal, 47 (2): 227-242.

Gallart, F., Llorens, P., Latron, J. (1994). Studying the role of old agricultural terraces on runoff generation in a Mediterranean small mountainous catchment. Journal of Hydrology, 159: 291-303. 
García-Ruiz, J. M. (2010). The effects of land uses on soil erosion in Spain: A review. Catena, 81: 1-11.

García-Ruiz, J. M., Puigdefábregas, J. (1982). Formas de erosión en el flysch eoceno surpirenaico. Cuadernos de Investigación Geográfica, 8: 83-126.

GARCÍA-Ruiz, J. M., VALERO-GARCÉS, B. (1998). Historical geomorphic processes and human activities in the Central Spanish Pyrenees. Mountain Research and Development, 18 (4): 309-320.

García-Ruiz, J. M., LAna-Renault, N. (2011). Hydrological and erosive consequences of farmland abandonment in Europe, with special reference to the Mediterranean region-A review. Agriculture, Ecosystems and Environment, 140: 317-338.

García-Ruiz, J. M., Lasanta, T., Ortigosa, L., Ruiz-Flaño, P., Martí, C., González, C. (1995). Sediment yield under different land-uses in the Spanish Pyrenees. Mountain Research and Development, 15 (3): 229-240.

García-Ruiz, J. M., Lasanta, T., Ruiz-Flaño, P., Ortigosa, L., White, S., González, C., MARTí, C. (1996). Land-use changes and sustainable development in mountain areas: a case study in the Spanish Pyrenees. Landscape Ecology, 11 (5): 267-277.

García-Ruiz, J. M., Martí-Bono, C., Lorente, A., Beguería, S. (2002). Geomorphological consequences of frequent and infrequent rainfall and hydrological events in Pyrenees mountains in Spain. Mitigation and Adaptation Strategies for Global Change, 7: 303-320.

García-Ruiz, J. M., Regües, D., Alvera, B., Lana.Renault, N., Serrano-Muela, E., Nadal-Romero, E., Navas, A., Latron, J., Marti-Bono, C., Arnáez, J. (2008). Flood generation and sediment transport in experimental catchment affected by land use changes in the central Pyrenees. Journal of Hydrology, 356: 245-260.

García-Ruiz, J. M., Lana.Renault, N., Begufria, S., Lasanta, T., Regües, D., Nadal-Romero, E., Serrano-Muela, M. P., López Moreno, J. I., Alvera, B., Marti-Bono, C., Alatorre, L. C.. (2010). From plot to regional scales: Interactions of slope and catchment hydrological and geomorphic processes in the Spanish Pyrenees. Geomorphology, 120: 248-257.

García-Ruiz, J. M., López-Moreno, J. I., Vicente-Serrano, S. M., Lasanta, T., Beguería, S. (2011). Mediterranean water resources in a Global Change scenario. Earth-Science Reviews, 105 (3-4): 121-139.

Giorgi, F. (2002). Variability and trends of subcontinental scale surface climate in the twentieth century. I. Observations. Climate Dynamics, 18: 675-691.

Giráldez, J. V., LAguna, A., GonZÁlez, P. (1989). Soil conservation under minimum tillage techniques in Mediterranean dry farming. In: Soil erosion protection measures in Europe (Schwetmann, U., Rickson, R. J., Auerswald, K., Eds.), Soil Techonology Series, pp. 139-148. 
Gómez, J. A., Romero, P., GirÁldeZ, J. V., Fereres, E. (2004). Experimental assessment of runoff and soil erosion in an olive grove on a Vertic soil in southern Spain as affected by soil management. Soil Use and Management, 20: 426-431.

González-Hidalgo, J. C., De Luis, M., Batalla, R. J. (2009). Effects of the largest daily events on total soil erosion by rainwater. An analysis of the USLE database. Earth Surface Processes and Landforms, 34: 2070-2077.

González-Hidalgo, J. C., Batalla, R. J., Cerdà, A., De luís, M. (2010). Contribution of the largest events to suspended sediment transport across the USA. Land Degradation and Development, 20: 83-91.

GonzÁlez-Hidalgo, J. C., Peña-Monné, J. L., De Luis, M. (2007). A review of daily soil erosion in Western Mediterranean areas. Catena, 71: 193-199.

González-Hidalgo, J. C., Batalla, R. J., Cerdè, A. (in press). Catchment size and largest daily events contribution to suspended sediment load at continental scale. Catena. Doi: 10.1016/j.catena.2010.10

González-Hidalgo, J. C., Batalla, R. J., Cerdà, A., De Luis, M. (2012). A regional analysis of the effects of largert events on soil erosion. Catena, 95: 85-90.

Grove A. T., Rackham, O. (2001). The Nature of Mediterranean Europe: An Ecological History. Yale University Press, London.

Hjelmfelt, A. T., Kramer, L. A., Spomer, R. G. (1986). Role of large events in average soil loss. In Proc. 4th Federal Interagency Sedimentation Conference, 1, USGS, Denver, Colorado, 3.1 to 3.9 .

Kosmas, C., Danalatos, N., Cammeraat, L. H., Chabart, M., Diamantopoulos, J., Farand, R., Gutiérrez, L., Jacob, A., Marqués, H., Martínez-Fernández, H., Mizara, A., Moustakas, N., Nicolau, J. M., Oliveros, C., Pinna, C., Puddu, R., Puigdefábregas, J., Roxo, M., Simao, A., Stamou, G., Tomasi, N., Usai, D., VACCA, A. (1997). The effect of land use on runoff and soil erosion rates under Mediterranean conditions. Catena, 29: 45-59.

Kundzewicz, Z. W., RadZiejewski, M., Pińskwar, I. (2006). Precipitation extremes in the changing climate of Europe. Climate Research, 31: 51-58.

Landwehr, J. M., Matalas, N. C., Wallis, J. R. (1979). Probability weighted moments compared with some traditional techniques in estimating Gumbel parameters and quartiles. Water Resources Research, 15 (5): 1055-1064.

Larson, W. E., Lindstrom, M. J., Schumacher, T. E. (1997). The role of severe storm in soil erosion: a problem needing consideration. Journal of Soil and Water Conservation, 52: 90-95.

LASANTA, T. (1988). The process of desertion of cultivated areas in the Central Spanish Pyrenees. Pirineos, 132: 15-36.

LaSANTA, T. (1989). Evolución reciente de la agricultura de montaña: El Pirineo aragonés. Geoforma Ediciones, Logroño, 220 pp. 
Lasanta, T., Vicente-Serrano, S. M. (2007). Cambios en la cubierta vegetal en el Pirineo aragonés en los ultimos 50 años. Pirineos, 162: 125-154.

Lasanta, T., Beguería, S., García-Ruiz, J. M. (2006). Geomorphic and hydrological effects of traditional shifting agriculture in a Mediterranean mountain area, Central Spanish Pyrenees. Mountain Research and Development, 26 (2): 146-152.

Lasanta, T., Nadal-Romero, E., Serrano-Muela, P., Vicente-Serrano, S. M., GarcíaRuiz, J. M. (2010). Escorrentía y erosión tras el abandono de tierras de cultivo en montaña: resultados de la Estación Experimental "Valle de Aísa". Pirineos, 165: 115-133.

Lenzi, M. A., MAO, L., Comiti, F. (2003). Interannual variation of suspended sediment load and sediment yield in an alpine catchment. Hydrological Sciences Journal, 48: 899-915.

Lewis, T., Braun, C., Hardy, D. R., Francus, P., Bradley, R. S. (2005). An extreme sediment transfer event in a Canadian High Arctic stream. Arctic, Antarctic and Alpine Research, 37: 477-482.

Llasat, M. C., Rigo, T., Barriendos, M. (2003). The 'Montserrat-2000' flash-flood event: a comparison with the floods that have occurred in the northeastern Iberian Peninsula since the 14th century. International Journal of Climatology, 23: 453-469.

Llorens, P., Latron, J., Gallart, F. (1992). Analysis of the role of agricultural abandoned terraces on the hydrology and sediment dynamics in a small mountainous basin. Pirineos, 139: 27-46.

LÓPEZ-BERMúdEZ, F., RoMERO-DíAZ, A. (1992-1993). Génesis y consecuencias erosivas de las lluvias de alta intensidad en la región mediterránea. Cuadernos de Investigación Geográfica, 18-19: 7-28.

LÓPEZ-BERMúdEZ, F., GARCÍA-RUIZ, J. M. (2008). La degradación del suelo por erosión hídrica en España. En Erosión y degradación del suelo agrícola en España (Cerdà, A., Ed.), Universidad de Valencia, Valencia, pp. 11-51.

López-Bermúdez, F., Navarro Hervás, F., Montaner, E. (1979). Inundaciones catastróficas, precipitaciones torrenciales y erosión en la provincia de Murcia. Papeles de Geografía, 8: 49-91.

López-Moreno, J. I., Beniston, M. (2009). Daily precipitation intensity projected for the 21st century: seasonal changes over the Pyrenees. Theoretical and Applied Climatology, 95: 375-384.

Lorente A., García-Ruiz, J. M., Beguería, S., ArnÁEz, J. (2002). Factors explaining the spatial distribution of hillslope debris flows. A case study in the Flysch Sector of the Central Spanish Pyrenees. Mountain Research and Development, 22 (1): 32-39.

MacDonald, D., Crabtree, J. R., Wiesinger, G., Dax, T., Stamou, N., Fleury, P., GutiérReZ LazPitA, J., GibON, A. (2000). Agricultural abandonment in mountain 
areas of Europe: environmental consequences and policy response. Journal of Environmental Management, 59: 47-69.

Meade, R. H., YuZYK, T. R., Day, T. J. (1990). Movement and storage of sediment in rivers of the United States and Canada. The Geology of North America, Vol. 0-1, Surface Water Hydrology, The Geologic al Society of America, pp. 225-280.

Morán-Tejeda, E., Ceballos-Barbancho, A., Llorente-Pinto, J. M. (2010). Hydrological response of Mediterranean headwaters to climate oscillations and land-cover changes: the mountains of Duero River basin (Central Spain). Global and Planetary Change, 72: 39-49.

Nadal-Romero, E., Martínez Murillo, J. F., Vanmaercke, M., Poesen, J. (2011). Scale-dependency of sediment jield from badland areas in Mediterranean environments. Progress in Physical Geography, 35 (3): 297-332.

Nunes, A., Coelho, C., De Almeida, A., Rodrigues, A. (2010). Soil erosion and hydrological response to land abandonment in a central inland area of Portugal. Land Degradation and Development, 21: 260-273.

Pardini, G., Gispert, M., Dunjó, G. (2004). Relative influence of wildfire on soil properties and erosion processes in different Mediterranean environments in NE Spain. The Science of the Total Environment, 328: 237-246.

Poesen, J., Hooke, J. M. (1997). Erosion, flooding and channel management in Mediterranean environments of southern Europe. Progress in Physical Geography, 21 (2): 157-199.

Poesen, J., Van Wesemael, B., Govers, G., Martínez-Fernández, J., Desment, J., Vandaele, K., Quine, T., Degraer, G. (1997). Patterns of rock fragment cover generated by tillage erosion. Geomorphology, 18: 183-197.

Räisänen J., Hansson, U., Ullerstig, A., Döscher, R., Graham, L. P., Jones, C., Meier, H., Samuelsson, P., Willén, U. (2004). European climate in the late twenty-first century: regional simulations with two driving global models and two forcing scenarios. Climate Dynamics, 22: 13-31.

Ramos, M. C., Martínez-Casasnovas, J. A. (2009). Impacts of annual precipitation extremes on soil and nutrient losses in vineyards of NE Spain. Hydrological Processes, 23: 224-235.

Rounsevell, M. D. A., Reginster, I., Araúuo, M. B., Carter, T. R., Dedoncker, N., Ewert, F., House, J. I., KankaAnpä̈̈, S., Leemans, R., Metzger, M. J., Schmit, C., Tuck, G. (2006). A coherent set of land use change scenarios for Europe. Agriculture, Ecosystems and Environment, 11: 57-68.

Ruiz-Flaño, P. (1993). Procesos de erosión en campos abandonados del Pirineo. Geoforma Ediciones, Logroño, 191 pp.

Ruiz-Flaño, P., García-Ruiz, J. M., Ortigosa, L. (1992). Geomorphological evolution of abandoned fields. A case study in the Central Pyrenees. Catena, 19: 301-308. 
Schnabel, S., Gómez Amelia, D., Ceballos, A. (1998). Eventos extremos y erosión en cárcava. In: Investigaciones recientes de la Geomorfología española (Gómez Ortiz, A., Salvador, F., Schulte, L., García Navarro, A., Eds.). Universitat de Barcelona, Barcelona, pp. 143-151.

Taillefumier, F., Piégay, H. (2003). Contemporary land use changes in prealpine Mediterranean mountains. A multivariate GIS-based approach applied to two miunicipalities in the Southern French Prealps. Catena, 51: 267-296.

Thornes, J. B. (1985). The ecology of erosion. Geography, 70: 222-235.

Thornes, J. B. (1999). The hydrological cycle and the role of water in Mediterranean environments. In: Rural planning from an environmental Systems perspective (Golley F.B., Bellot, F.B., Eds.), Springer, pp. 85-107.

Vanmarcke, M., Poesen, J., Verstraeten, G., De Vente, J., Ocakoglu, F. (2011). Sediment yield in Europe: Spatial patterns and scale dependency. Geomorphology, 130: $142-161$.

Wei, W., Chen L. D., Fu, B. J., Chen, J. (2010). Water erosion response to rainfall and land use in different drought-level years in a loess hilly area of China. Catena, 81 (1): 24-31.

White, S., García Ruiz, J. M., Martí-Bono, C., Valero Garcés, B., Errea, M. P., Gómez-Villar, A. (1997). The 1996 Biescas campsite disaster in the Central Spanish Pyrenees, and its temporal and spatial context. Hydrological Processes, 11: $1797-1812$.

WischmeIER W. H. (1962). Storms and soil conservation. Journal of Soil and Water Conservation, 17: 55-59.

Zhang, J, Garbrecht, J. D. (2002). Precipitation retention and soil erosion under varying climate, land use, and tillage and cropping systems. Journal of the American Water Resources Association, 38: 1241-1253.

Zolina, O., Kapala A., Simmer C., Gulev S. K. (2004). Analysis of extreme precipitation over Europe from different reanalysis: a comparative assessment. Global and Planetary Chang, 44: 129-161.

Zuzel, J. F., Allmaras, R. R., Greenwalt, R. N. (1993). Temporal distribution of runoff and soil erosion at a site in Northeast Oregon. Journal of Soil and Water Conservation, 48: 373-378. 